\title{
WATER MOVEMENT IN SOIL UNDER MICRO TRICKLE IRRIGATION SYSTEM
}

\author{
A. A. M. Elmesery ${ }^{1}$
}

\section{ABSTRACT}

Water distribution pattern is influenced by application rate of water and soil properties. In this study, low application rate " $q$ " of water was used as $0.25,0.5,1.2$, and $2 \mathrm{Lh}^{-1}$ and two types of soil sandy soil and clay soil. Wet radius at the surface $(x)$, diagonal wetting front $(z)$, and the depth of the wetting front (y) under the dripper were measured at different application times " $t$ " of (30 to $270 \mathrm{~min}$ ) for each treatment. The results showed that wetted front advance in directions $x, y$ and $z$ were represented by derived function expressed as $x, y, z=c_{1} q^{c} t^{b}$, where: $c_{1}, c$ and $b$ are constants depend on soil type and required direction.

\section{INTRODUCTION}

7 rickle irrigation allows a large degree of water saving enabling accurate application of irrigation amounts according to crop

1 water requirements. Under optimum management, trickle irrigation systems will reduce the water losses caused by evaporation and by deep percolation. The use of this technique is relatively recent and little information is known about the movement of the water in soil profile. Awady and Mostafa (1975), studied infiltration of water from trickles into loamy soils. The study gives details for proper trickle application including puddling, and rate of wet front advance in the different direction. Infiltration rate speed was described in terms of hydraulic conductivity, rate of trickling and time in dimensionless power groups. The size of the wetted soil volume under emitters is an important field characteristic in trickle irrigation frequency and application rate determining the soil water content and as a result root distribution and patterns of plant water uptake, (Acar et al;2009; Assouline; 2002). The wetted soil volume under an emitter can be determined for the purpose of

${ }^{1}$ Ass. Prof. of Agric. Eng., Agric. Eng. Dept., Fac. Of Agric., Al-Azhar University.

Misr J. Ag. Eng., July 2011 
estimating the available soil water as the product of percent of wetted area and depth of rooting. The dimensions of water depth and percentage of the wetted area depend on the emitter discharge spacing, and soil properties (Keller and karmeli, 1974, Assouline; 2002). The boundaries of the wetted soil volume are reasonably well defined and are surrounded by drier soil (Zur, 1996; Wooding, 1968). Mitchell and Lembke (1981) reported that increasing emitter discharge reduced lateral and increased the vertical movement of water under silt - clay - loam soil. Clarket et al. 1993 reported that lateral movement of water varied between 15.5 and 20 $\mathrm{cm}$ by the use of 1.5- $1.9 \mathrm{Lh}^{-1}$ emitter discharge in sandy soil conditions. In trickle irrigation, the soil serves less as a reservoir for water than for conventional irrigation because the water that is withdrawn from the root zone is continually replenished. As a result, soil type dose not play much role in irrigation scheduling in trickle irrigation (Lubane et al.2002) .However, the soil type and the application rate of water, both influence the pattern of water movement in the soil. The distances between emitter would determine the degree of overlap between neighboring wetted circles. The volume of water applied per irrigation also affects the width and depth of the wetted soil volume and therefore influences the optimal emitter spacing. In conventional trickle, the wetting patterns during application consist of two zones; (A) a saturated zone close the emitter, and (B)a zone where the water content decreases toward the wetting front. Increasing the emission rate generally results in an increase in the wetted soil diameter and a decrease in wetted depth (Schwartzman and Zur 1986). In micro drip irrigation, observation seems to indicate that there is no saturated zone and that the wetted soil volume is greater compared with that for conventional emitter discharges (Koenig, 1997). Ainechee et al, (2009) illustrated that information on moisture distribution patterns under point source trickle emitters is a pre-requisite for the design and operation of trickle irrigation systems. This will ensure precise placement of water and fertilizer in the active root zone. The distribution pattern is influenced by the soil properties and the behavior of applied water. Abdoet al, (2010) compared traditional trickle flow 81/h and ultralow rate system $0.41 / \mathrm{h}$ for the same water quantity $2.41 / \mathrm{h}$, She said also wetting pattern front for sand and clay soils at traditional trickle 
flow were faster than wetting pattern front at ultra low rate system, which led to a significant loss in the amount of water by deep percolation in a short time. The main object of this present study is determined the water pattern at low application rate and different soil types (sand and clay).

\section{MATERIALS AND METHODS}

The experiments were carried out in the Irrigation Laboratory, Agricultural Engineering Department, Al-Azhar University. Transparent plastic bag of cylindrical shape $50 \mathrm{~cm}$ diameter and $60 \mathrm{~cm}$ depth were used. Sandy and clayey soils were used. Some physical and chemical characteristics of the studied soil are recorded in table (1) were measured in the Laboratory of Soil and Water Department, Faculty of Agriculture, Al-Azhar University in Nasr City . PCJ (on - line dripper) was used Fig.1. The specifications of PCJ dripper have large water passages. Working pressure range is 0.5 to 4.0 bar. PCJ, on - line dripper meets ISO 9261 standards. The dripper technical data are in table (2). Four application rates were studied; $0.25,0.5,1.2$, and $2 \mathrm{Lh}^{-1}$, the discharge $0.25 \mathrm{Lh}^{-1}$ was obtained by branching of $0.5 \mathrm{Lh}^{-1}$.

Table (1): Some soil physical characteristics

\begin{tabular}{|c|c|c|c|c|c|c|c|c|c|c|}
\hline \multirow{2}{*}{$\begin{array}{l}\text { Soil } \\
\text { type }\end{array}$} & \multicolumn{3}{|c|}{ Particle size distribution \% } & \multirow{2}{*}{$\begin{array}{c}\mathrm{CaCo}_{3} \\
\%\end{array}$} & \multirow{2}{*}{$\begin{array}{c}\text { O.M } \\
\%\end{array}$} & \multirow{2}{*}{$\begin{array}{c}\text { B.density } \\
\mathbf{g} / \mathrm{cm}^{3}\end{array}$} & \multirow{2}{*}{$\begin{array}{l}\text { H. con. } \\
(\mathrm{Cm} / \mathrm{h})\end{array}$} & \multirow{2}{*}{$\begin{array}{c}\text { Field } \\
\text { cap. } \\
\%\end{array}$} & \multirow{2}{*}{$\begin{array}{c}\text { P.W. P } \\
\%\end{array}$} & \multirow{2}{*}{$\begin{array}{c}\text { Available } \\
\text { water } \\
\%\end{array}$} \\
\hline & Co.S. & M. s. & $\begin{array}{l}\text { Fine } \\
\text { sand }\end{array}$ & & & & & & & \\
\hline sand & 0.12 & 88.37 & 11.51 & 1.13 & 1.93 & 1.57 & 9.12 & 7.85 & 2.93 & 4.92 \\
\hline \multirow{2}{*}{ clay } & Silt & clay & sand & \multirow{2}{*}{31.23} & \multirow{2}{*}{3.38} & \multirow{2}{*}{1.30} & \multirow{2}{*}{3.04} & \multirow{2}{*}{28.22} & \multirow{2}{*}{12.07} & \multirow{2}{*}{16.15} \\
\hline & 12.15 & 55.22 & 32.63 & & & & & & & \\
\hline
\end{tabular}

\section{Methods}

The transparent plastic bag was packed with soil which was air dried. Emitter was placed in the geometrical center at the top of the soil surface. Three replicates were tested on each soil. After one hour from irrigation end, the position of wetting front (radius of wetting) was measured. Accurately and slowly, the bag was cut (small cutting) and the wetted sample core was divided and the depth wetted and the diagonal wetted were measured. 


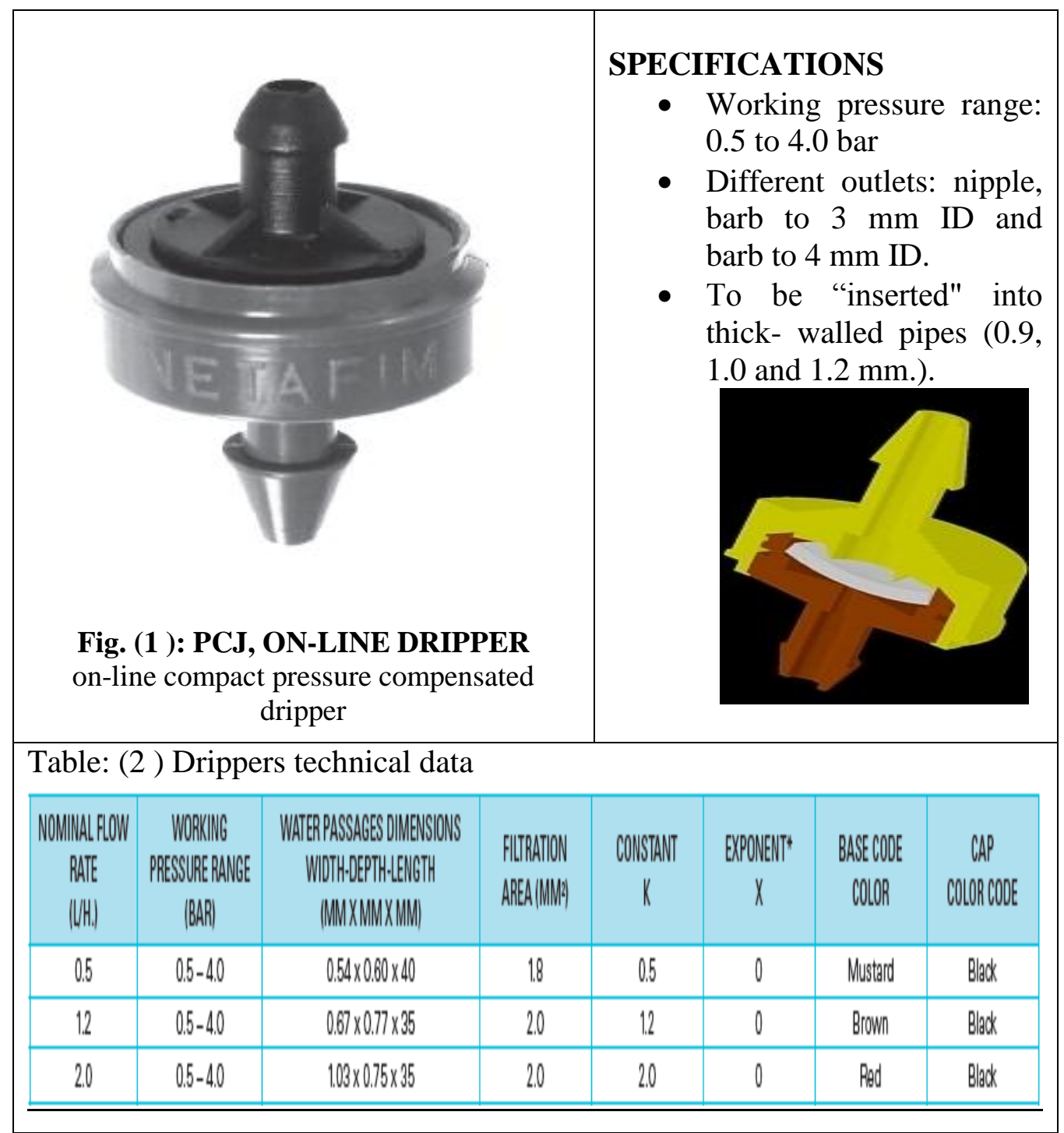

Before using PCJ dripper, 22 emitter were tested at different operating pressures of $0.5,1,1.5$, and 2 bar. Emitter discharge was collected at each operating pressure. The manufactures coefficient of variation "CV" was measured.

The moisture content of sample (pattern core) was measured under dripper and three point in each direction (x, y, z). Traditional oven method was used to determining of volumetric moisture continent. 


\section{RESULTS AND DISCUSSIONS}

The main objective of this research is to determine water distribution (wetting pattern) in sandy and clayey soils with low application rate, $0.25,0.50,1.2$, and $2 \mathrm{~L} / \mathrm{h}$. $(0.25$ and $0.50 \mathrm{~L} / \mathrm{h}$ is ultralow rate, 1.2 and $2 \mathrm{~L} / \mathrm{h}$ is micro dripper). The wetting patterns are characterized by depth of wetting front (y) under the point source (emitter), the radial wetting front at the surface (x) and diagonal wetting front advance (z).These variables are influenced by the application rate, irrigation duration time, and soil type.

\section{Dripper test:}

PCJ on - line dripper is new dripper having constant discharge at working range 0.5 to 4.0 bar. The coefficient of variation " $\mathrm{CV}$ " was estimated for 22 drippers, values of "CV" were very low. "CV" was 0.04 to 0.06 . Fig (2) shows the mean emitter discharge at pressure operation of $0.5,1,1.5$ and 2 bar. From Fig (2) the mean discharge was constant at different operation pressures. These results do not agree with the famous Killer equation which is: $q=k h^{x}$. But in this case the exponent " $\mathrm{x}$ " equals " 0 " as in table (2).

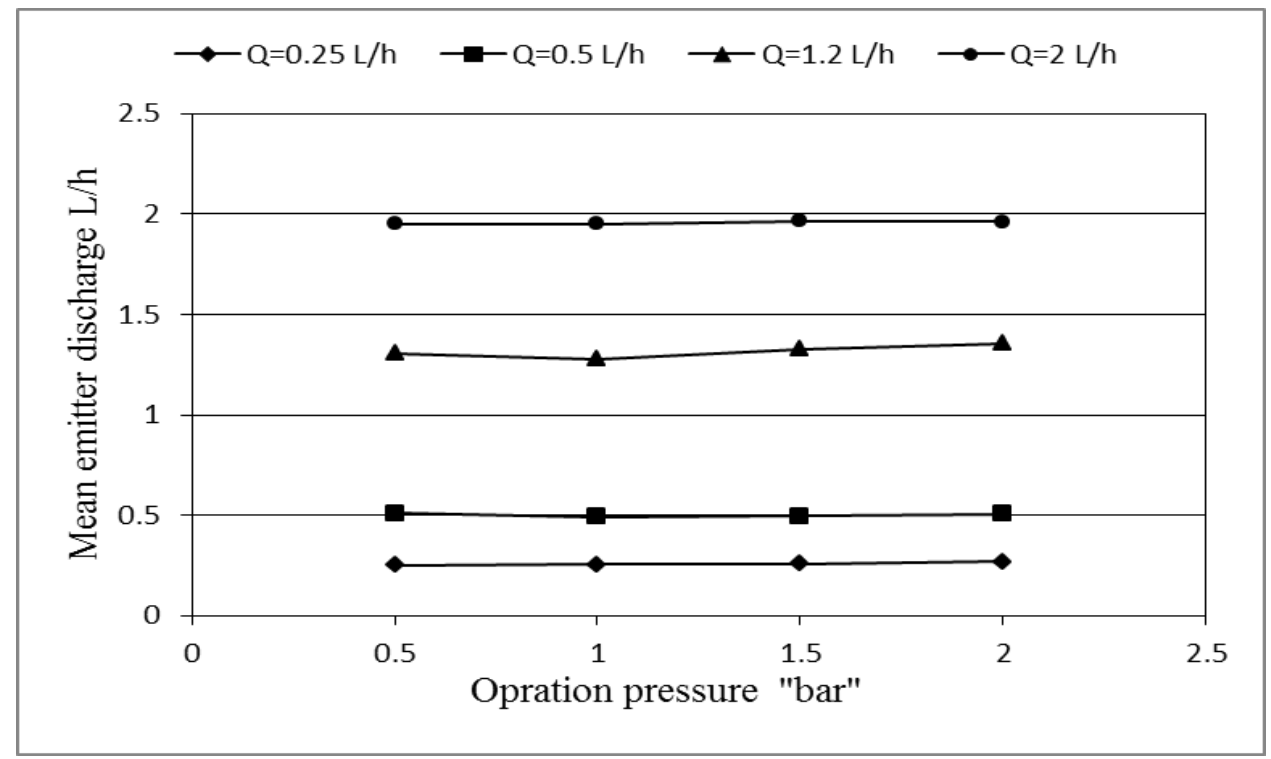

Fig. (2): Relation between operation pressure "bar" and mean emitter discharge $\mathrm{L} / \mathrm{h}$. 


\section{Water distribution in three directions:}

Fig (3) shows the relation between horizontal wetted front advance (x), vertical wetted front advance (y) and diagonal wetted front advance ( $\mathrm{z}$ ) and application time at different application rates in clayey soil and sandy soil. From Fig (3) in sand soil, the values of horizontal wetted front advances (x) cm. at application times of 30 and $270 \mathrm{~min}$. were $(9.4,13.4)$, $(12.0,16.4),(14,20.7)$ and $(14.4 \mathrm{~cm}, 22.4 \mathrm{~cm})$ at application rates $0.25,0.5$, 1.2 , and $2 \mathrm{~L} / \mathrm{h}$ respectively. The values of vertical wetted front advance (y) $\mathrm{cm}$. at application times of 30 and $270 \mathrm{~min}$. were $(8.3,21.2),(11.6$, $28.0),(17.3,36.8)$ and $(23.1 \mathrm{~cm}, 47 \mathrm{~cm})$ at application rates $0.25,0.5,1.2$, and $2 \mathrm{~L} / \mathrm{h}$ respectively. The values of diagonal wetted front advance $(\mathrm{z})$ $\mathrm{cm}$. at application time of 30 and $270 \mathrm{~min}$. were $(10.1,18.5),(11.6,26.4)$, $(16.4,30.0)$ and $(20 \mathrm{~cm}, 40 \mathrm{~cm})$ at application rates $0.25,0.5,1.2$ and 2 $\mathrm{L} / \mathrm{h}$ respectively. Also, in clayey soil, the values of $(\mathrm{x}) \mathrm{cm}$. at application times of 30 and $270 \mathrm{~min}$. were $(6.4,10.4),(8.0,13.4),(9.5,16.3)$ and $(10.6 \mathrm{~cm}, 18.9 \mathrm{~cm})$ at application rates $0.25,0.5,1.2$, and $2 \mathrm{~L} / \mathrm{h}$ respectively. The values of $(\mathrm{y}) \mathrm{cm}$. at application times of 30 and 270 min. were $(7,14),(9.0,18.2),(12.7,29.0)$ and $(14.7 \mathrm{~cm}, 33.8 \mathrm{~cm})$ at application rates $0.25,0.5,1.2$, and $2 \mathrm{~L} / \mathrm{h}$ respectively. The values of $(\mathrm{z})$ $\mathrm{cm}$. at application times of 30 and $270 \mathrm{~min}$. were (7.0, 13.2), (9, 15.9), $(12.3,25.0)$ and $(13.7 \mathrm{~cm}, 27 \mathrm{~cm})$ at application rates $0.25,0.5,1.2$ and 2 L/h respectively. From fig (3), a regression analysis showed that experimental data of the $\mathrm{x}, \mathrm{y}$ and $\mathrm{z}(\mathrm{cm})$ exposed power functions in relation to application time (min) as follows which agrees with Awady and Mostafa (1975).

$$
x, y, z=a t^{b} \ldots \ldots \ldots \ldots(3)
$$

Where:

$$
\begin{aligned}
& \mathrm{x}=\text { horizontal wetted front advance, } \mathrm{cm} \\
& \mathrm{y}=\text { vertical wetted front advance, } \mathrm{cm} \\
& \mathrm{z}=\text { diagonal wetted front advance, } \mathrm{cm} \\
& \text { " } a \text { " and " } \mathrm{b} \text { " parameter depend on direction of wetted front } \\
& \quad \text { advance ( } \mathrm{x}, \mathrm{y} \text { and } \mathrm{z} \text { ), soil type and application rate. }
\end{aligned}
$$


The values of these parameters are summarized in table (4) at different directions and different application rates (A.R). Also the value of $(\mathrm{CV})$ between values of parameter " $b$ " was very low. Therefore the mean value of parameter " $b$ " was taken to represent.

Table (4) Parameters $\left(a_{x}, a_{y}, a n d a_{z}\right)$ and $\left(b_{x}, b_{y}\right.$ and $\left.b_{z}\right)$ at different application rates in sandy soil and clayey soils.

\begin{tabular}{|c|c|c|c|c|c|c|c|c|c|c|c|c|}
\hline \multirow{3}{*}{$\begin{array}{l}\text { A.R } \\
\text { L/h }\end{array}$} & \multicolumn{6}{|c|}{ Sandy soil } & \multicolumn{6}{|c|}{ Clayey soil } \\
\hline & \multicolumn{2}{|c|}{$\mathbf{X}$} & \multicolumn{2}{|c|}{$\mathbf{y}$} & \multicolumn{2}{|c|}{$\mathbf{Z}$} & \multicolumn{2}{|c|}{$\mathbf{X}$} & \multicolumn{2}{|c|}{$\mathbf{y}$} & \multicolumn{2}{|c|}{$\mathbf{Z}$} \\
\hline & $a_{x}$ & $b_{x}$ & $\alpha_{y}$ & $b_{y}$ & $a_{z}$ & $\boldsymbol{b}_{z}$ & $a_{x}$ & $b_{x}$ & $a_{y}$ & $b_{y}$ & $a_{z}$ & $b_{z}$ \\
\hline 0.25 & 4.944 & 0.186 & 2.314 & 0.384 & 3.175 & 0.314 & 2.608 & 0.247 & 2.137 & 0.34 & 2.306 & 0.203 \\
\hline 0.5 & 6.315 & 0.175 & 3.124 & 0.382 & 3.765 & 0.345 & 2.863 & 0.275 & 2.369 & 0.364 & 3.259 & 0.285 \\
\hline 1.2 & 7.378 & 0.189 & 5.133 & 0.352 & 6.344 & 0.279 & 4.165 & 0.244 & 3.343 & 0.386 & 3.812 & 0.337 \\
\hline 2 & 7.733 & 0.191 & 6.652 & 0.349 & 6.364 & 0.328 & 4.401 & 0.260 & 3.881 & 0.387 & 4.758 & 0.310 \\
\hline Mean & & 0.185 & & 0.366 & & 0.317 & & 0.257 & & 0.369 & & 0.284 \\
\hline
\end{tabular}

$a_{x}=$ Parameter " $a$ " for wetted horizontal (radius).

$a_{y}=$ Parameter " $a$ " for depth

$a_{z}=$ Parameter " $a$ " for diagonal

Figs. (4 and 5) indicate radius the relation between application rate (emitter discharge) $\left(\mathrm{Lh}^{-1}\right)$ and parameter "a" $\left(a_{x}, a_{y}\right.$, and $\left.a_{z}\right)$ The relation between parameter "a" (at different directions) was found as power equation at sandy and clayey soil as follows:

In sandy soil:

$$
\begin{aligned}
& a_{\mathrm{x}}=6.925 \mathrm{q}^{0.212} \ldots \ldots \ldots\left(\mathrm{R}^{2}=0.944\right) \\
& a_{\mathrm{y}}=4.629 \mathrm{q}^{0.515} \ldots \ldots \ldots\left(\mathrm{R}^{2}=0.997\right) \\
& a_{\mathrm{z}}=5.248 \mathrm{q}^{0.375} \ldots \ldots \ldots\left(\mathrm{R}^{2}=0.935\right) .
\end{aligned}
$$

In clayey soil:

$$
\begin{aligned}
& a_{\mathrm{x}}=3.718 \mathrm{q}^{0.278} \ldots \ldots \ldots\left(\mathrm{R}^{2}=0.950\right) \\
& a_{\mathrm{y}}=3.117 \mathrm{q}^{0.301} \ldots \ldots \ldots\left(\mathrm{R}^{2}=0.973\right) . \\
& a_{\mathrm{z}}=3.766 \mathrm{q}^{0.324} \ldots \ldots \ldots . .\left(\mathrm{R}^{2}=0.962\right)
\end{aligned}
$$




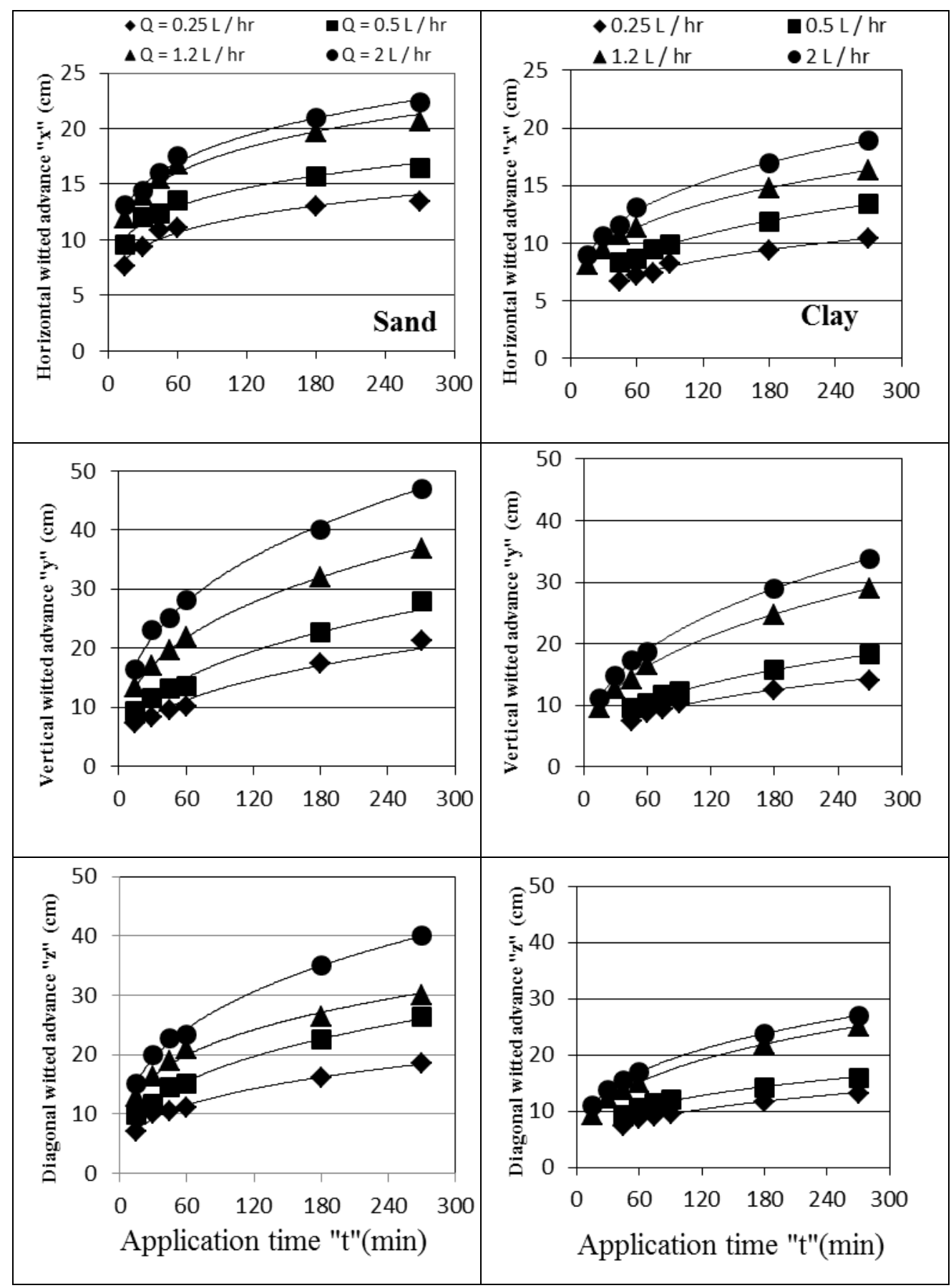

Fig. (3): Relation between wetting front advance (different directions $x, y$ and z) and application rate in clayey soil and sandy soils. 


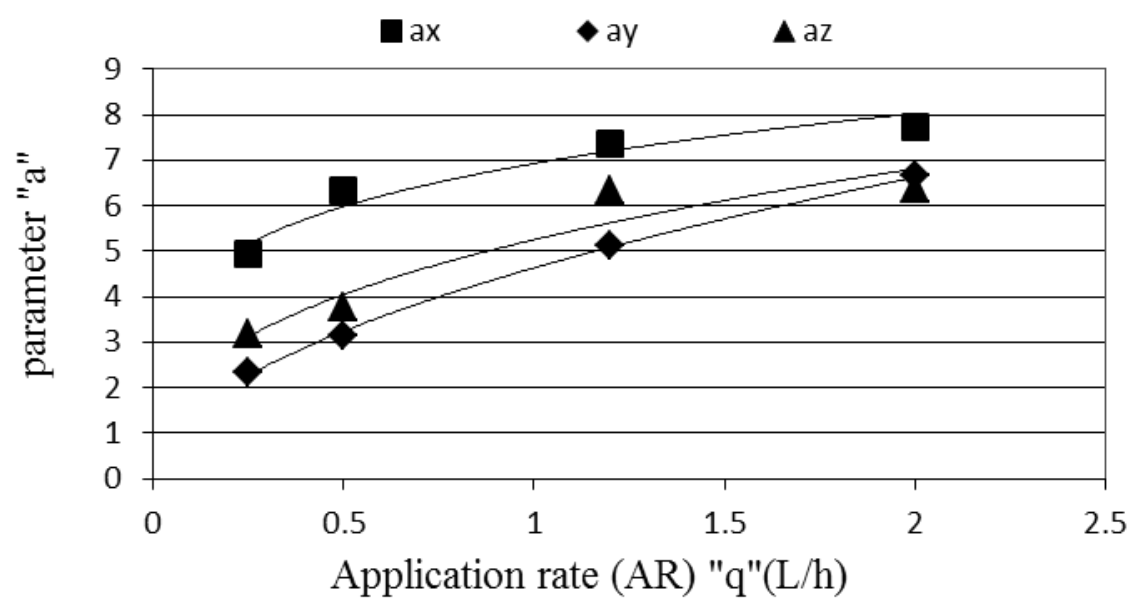

Fig. (4): Relation between emitter discharge and parameter "a" at different directions on sandy soil.

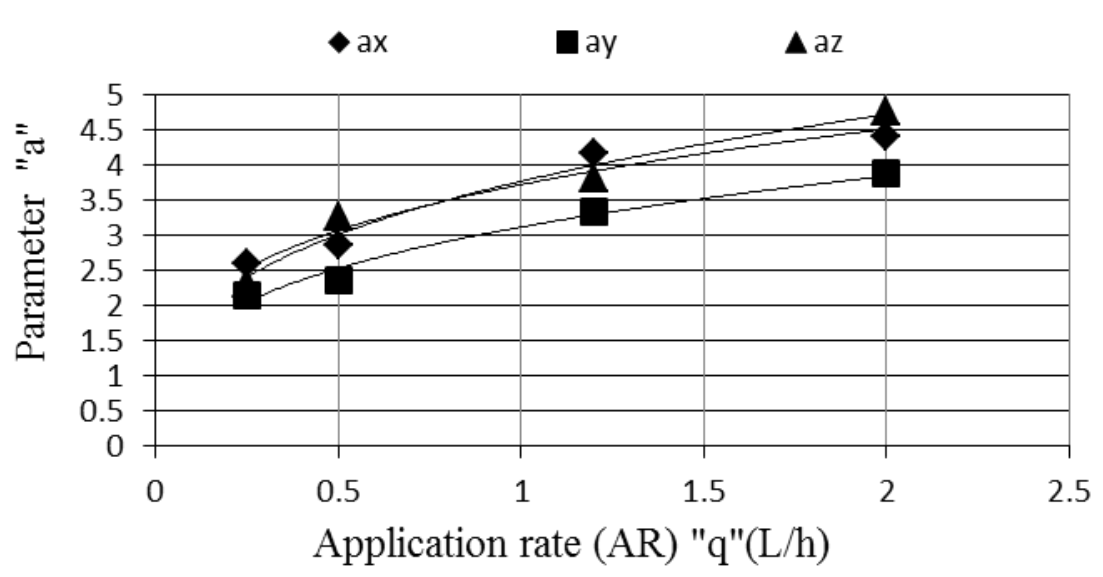

Fig. (5): Relation between emitter discharge and parameter "a" at different directions on clayey soil.

From equations (3), (4 to 9) and table (4) the final equations which determine $x, y$, and $z$ on sandy and clayey soils are: 
In sandy soil:

$$
\begin{aligned}
& x=6.925 q^{0.212} \times t^{0.185} \\
& y=4.629 q^{0.515} \times t^{0.366} \\
& z=5.248 q^{0.375} \times t^{0.317}
\end{aligned}
$$

In clayey soil:

$$
\begin{aligned}
& x=3.718 q^{0.278} \times t^{0.257} \\
& y=3.117 q^{0.301} \times t^{0.369} \\
& z=3.766 q^{0.324} \times t^{0.284}
\end{aligned}
$$

\section{Determination of water distribution velocity in soil:}

By using differential calculus for equations 10 to 15 (assuming "q" is constant ), the water distribution velocity was determined for directions $\mathrm{x}$ and $\mathrm{y}$ as follows:

On sand soil

$$
\begin{aligned}
& \bar{x}=1.269655(q)^{0.221} \times(t)^{-0.815} \\
& \bar{y}=1.694214(q)^{0.515} \times(t)^{-0.634} \\
& \bar{z}=1.663616(q)^{0.375} \times(t)^{-0.683}
\end{aligned}
$$

On clay soil

$$
\begin{aligned}
& \bar{x}=0.952812(q)^{0.278} \times(t)^{-0.478} \\
& \bar{y}=1.155152(q)^{0.307} \times(t)^{-0.632} \\
& \bar{z}=1.069544(q)^{0.324} \times(t)^{-0.716}
\end{aligned}
$$

Fig (6 and 7) illustrate the velocities of witted advanced in directions $x$ and $y$ at sandy and clayey soils with different application rates. 
These figures may give indicator of water movement in case of unsaturated soil.

Fig (8) illustrates the relation between $\mathrm{x}, \mathrm{y}$ and $\mathrm{z}$ observed and $\mathrm{x}, \mathrm{y}$ and $\mathrm{z}$ which were calculated by equations (10 to 15). The results gave agreement between those observed and calculated, with correlation coefficient $\left(R^{2}\right) 0.95$ - 0.97 in sandy and clayey soil respectively.

Figs. (9 and 10) illustrate the wetted distribution shape in sandy and clayey soils at different application times. The distribution of wetted fronts in directions $\mathrm{x}$ equal $\mathrm{y}$ and $\mathrm{z}$ at low application time, until 60, min but after this time the vertical wetted advance was higher than horizontal distance.

Table (5) shows that the moisture content in pattern core at different micro trickle application rates was equal and it is around field capacity. This result agrees with (Assouline, 2002), therefore the aeration ratio in soil is higher than traditional trickle methods which is suitable for roots growth.

Table (5): Pattern moisture content in soil at different application rates after one hour from irrigation end.

\begin{tabular}{|c|c|c|}
\hline Application rate $(\mathrm{l} / \mathrm{h})$ & $\begin{array}{c}\text { Mean moisture } \\
\text { content \% in pattern of } \\
\text { sand soil }(\mathrm{CV}=0.06)\end{array}$ & $\begin{array}{c}\text { Mean moisture } \\
\text { content \% in pattern of } \\
\text { clay soil }(\mathrm{CV}=0.06)\end{array}$ \\
\hline $0.25-0.5$ & 4.9 & 28 \\
\hline $1.2-2$ & 7.5 & 31 \\
\hline
\end{tabular}




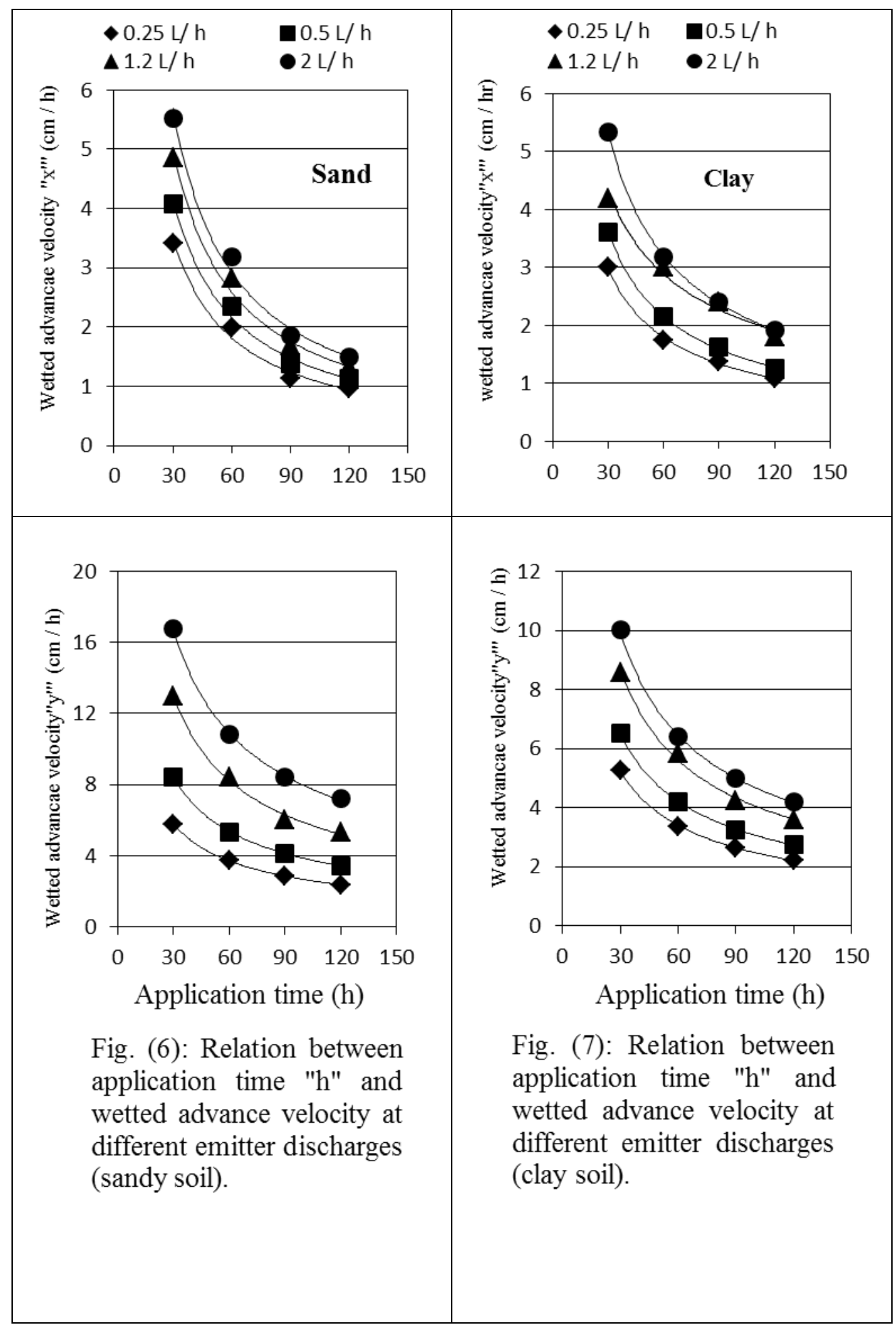




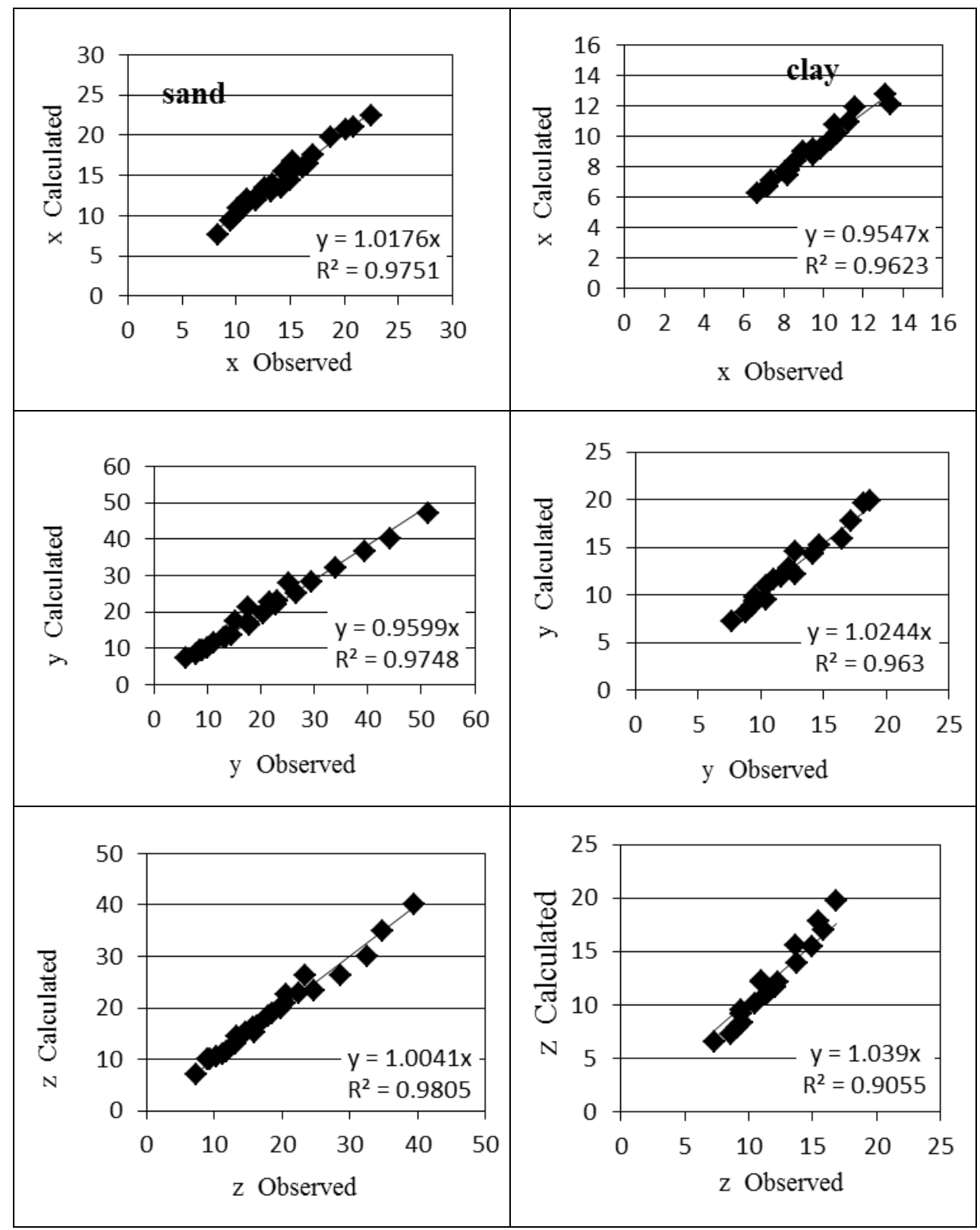

Fig. (8): Relation between wetted advance distance (x, y and z) observed and calculated. 

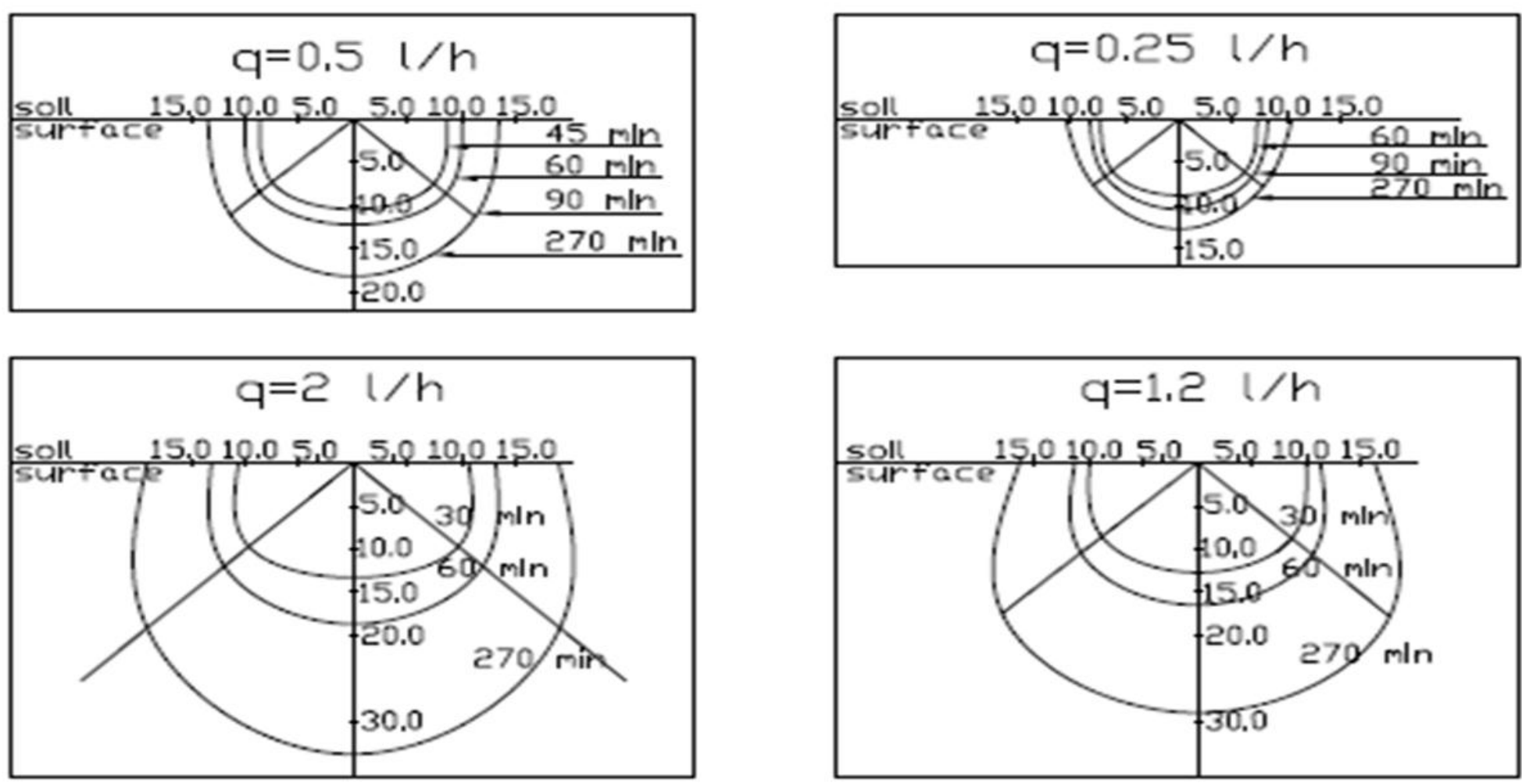

Dim. in $\mathrm{cm}$

Fig. 9: Wetting pattern at different application rate and application time (clayey soil) 

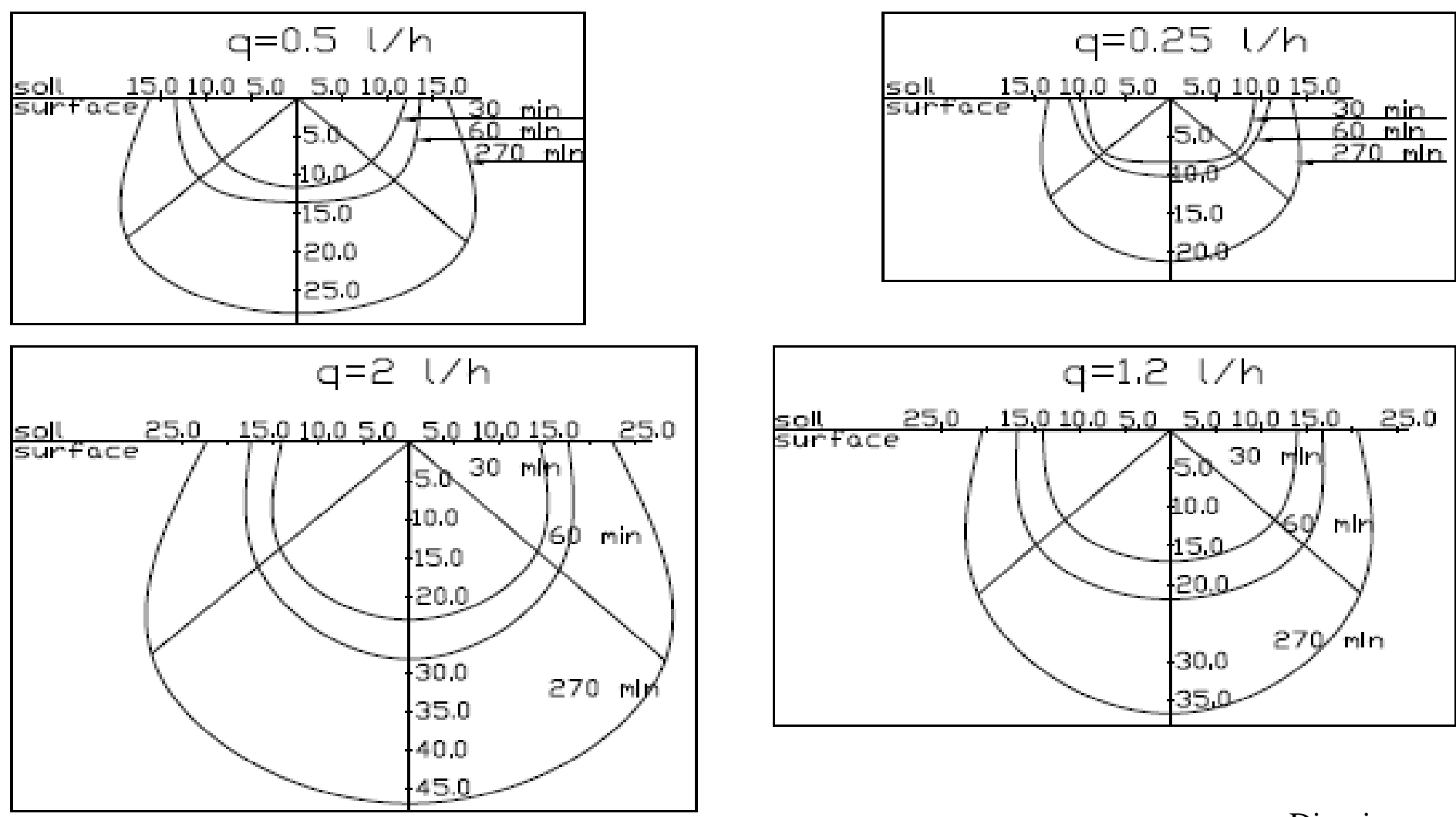

Dim. in $\mathrm{cm}$

Fig. 10: Wetting pattern at different application rate and application time (sandy soil) 


\section{CONCLUSION}

Water distribution pattern is influenced by application rate of water and soil properties. In this study low application rates "q" of water were used as $0.25,0.5,1.2$, and $2 \mathrm{Lh}^{-1}$ which two types of soil (sandy and clayey soils).Wetted front advance in horizontal direction $(\mathrm{x})$ is important to determine optimum line and dripper spacings on a line, whereas vertical wetting front advance (y) is important to cultivated crop roots growth and to prevent deep percolation. This study was performed on a micro application rate. Therefore, wetted pattern was different from conventional drip irrigation. The maximum values of $(\mathrm{x})$ in sandy and clayey soils at minimum application rate of $0.25 \mathrm{~L} / \mathrm{h}$ after $270 \mathrm{~min}$ time were $(13.4,10.4$ $\mathrm{cm})$ resp. But values of $(\mathrm{y})$ were $(24.2,12.7 \mathrm{~cm})$ resp. On the other hand, the maximum values of $(\mathrm{x})$ in sand and clayey soil at maximum application rate $2 \mathrm{~L} / \mathrm{h}$ after $270 \mathrm{~min}$ application time were $(22.4,18.9 \mathrm{~cm})$ resp, which values of $(y)$ were $(47,33.8 \mathrm{~cm})$ resp. Also, the results show that the mean pattern moisture content was $(28 \%)$ in clayey soil with application rates $(0.25$ and $0.5 \mathrm{~L} / \mathrm{h})$. It was $31 \%$ with application rates $(1.2$ and $2 \mathrm{~L} / \mathrm{h})$. The mean pattern moisture content was $(4.9 \%)$ in sandy soil with application rate $(0.25$ and $0.5 \mathrm{~L} / \mathrm{h})$, it was $7.5 \%$ with application rates $(1.2$ and $2 \mathrm{~L} / \mathrm{h})$. These results indicated that the aeration around roots zone was best at the different application rates used.

\section{REFERENCES}

Abdou, S.; M. Hegazi; A. El-Gindy and claudia (2010). performance of Ultra - Low rate of trickle irrigation. Misr.J. Ag. Eng. Vol. 27(2), pp. 549-563.

Acar, B.; R. Topak and F. Mikailsoy (2009). Effect of applied water and discharge rate on wetted soil volumein loam or clayloam soil from an irrigated trickle source. African. J. Ag. Research. Vol. 4 (1), pp. 049054.

Ainechee, G.; S. Boroom and M. Behzad (2009). Simulation of soil wetting pattern under point sours trickle irrigation. J. Appl. S. 9(6): $1170-1174$.

Assouline, S. (2002). The effects of micro-drip and conventional drip irrigation on water distribution and uptake.Soil.Sci. Am.J. 66:16301636. 
Awady, M. N. and Mostafa, M., (1975). Infiltration of water from tricklers into loamy soils, Egypt J. Soil Sci, Special Issue: 209 - 214.

Clark C. A.; F. S. Sramley and F. S. Zazueta (1993).Qualitative sensing of water movement from a pointsource emitter ona sandy soil. Transactions of ASAE, 9 (3): 299-303.

Keller, J. and D. Karmali (1974). Trickle irrigation design parameters. Transactions of ASAE , 17: 678- 684.

Koenig, E. (1997). Methods of micro-irrigation with very small discharges and particularly low application rates. Water Irrig. 365:32-38.

Lubana, P.P.; N .K. Narda and L. C. Brown(2002).Application of hemispherical model to predict radius of wetted soil volume under point source emitters for trickle irrigation tomatoes in Punjab state .ASAE., 32 ; 243-257.

Mitchell J. k.; and W. D. lembke (1981). Effect of discharge rate in heavy soil from a irrigation Trickle source .ASAE paper no : 81, p. 2081.

Schwartzan, M. and B. Zur (1986).Emitter spacing and geometry of wetted soil volume.J. Drain. Eng., 112: 242-253.

Wooding, RA. (1968). Steady infiltration form a shallow circular pond water, Res.4: 1259- 1273.

Zur, B. (1996).wetted soil volume as a design objective in trickle irrigation. Irrig. sci. 16:101-105.

الملخص العربي

حركة الماء في التربة تحت نظام الري بالتنقيط منخفض التصرف

علاء الدين المسيري*

يتأثر شكل البلل في التربة فى نظام الرى بالتنقيط على تصرف النقاط ونوع التربة وفترة إضافة

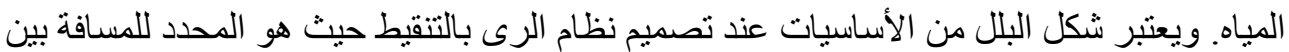

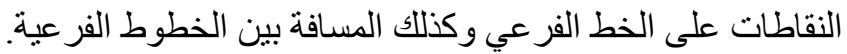

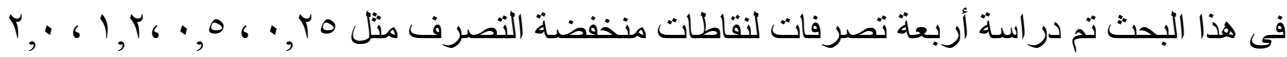

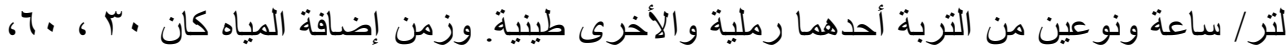
(

*أستاذ مساعد بقسم الهندسة الزراعية ـ كلية الزراعة بالقاهرة - جامعة الأزهر 


\section{القياسـاث}

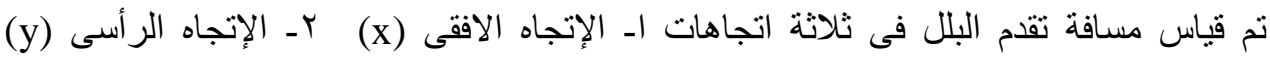

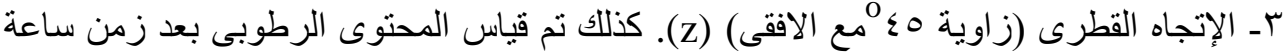
من نهاية الرى فى أماكن مختلفة من العينات.

الأنتائج

بعد تحليل النتائج، وجد أن العلاقة بين مسافة البلل فى الثلاث اتجاهات X, y, z مع زمن الإضافة و

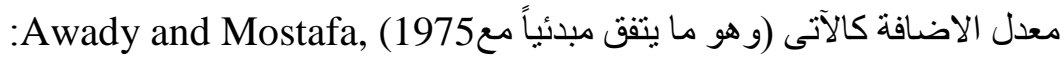

$$
\mathbf{x}, \mathbf{y}, \mathbf{z}=\mathbf{c}_{1} \mathbf{q}^{\mathbf{c}^{\mathbf{b}}}
$$

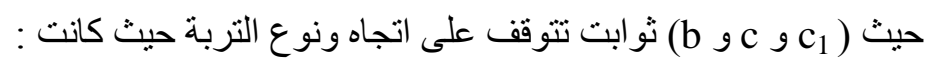

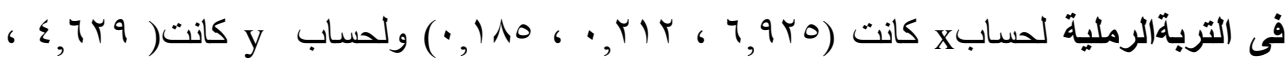

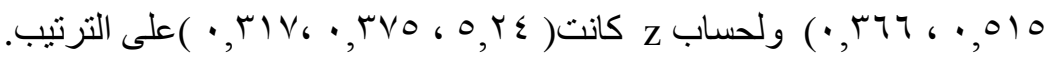

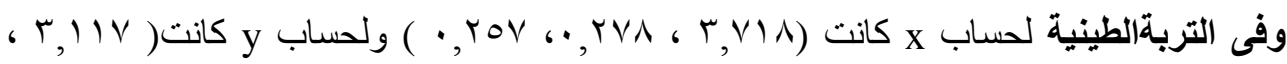

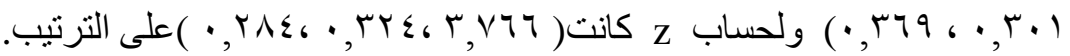

وتم اختبار المعادلات فى حساب قيم x, y, z ومقارنتها بالقيم المشاهدة وجد أن المعادلات دقيقة

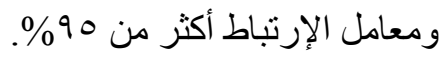

وجد أن المحتوى الرطوبى متقارب في جميع العينات ويمكن أن يمثل المتوسط الحسابى حيث كان معامل الاختلاف اقل من 7 •, •. 